\title{
AKSELERASI:
}

\section{DAMPAK COVID 19 TERHADAP PROSES PEMBELAJARAN DARING DI SEKOLAH DASAR NU GRENDEN PUGER}

\author{
Imam Musfi ${ }^{1}$, Abdul Karim ${ }^{2}$ \\ ${ }^{1}$ IAIN Jember, Jl. Mataram No.1 Mangli Jember, Jawa Timur Indonesia \\ Email: musfiterate1922@gmail.com, \\ ${ }^{2}$ IAIN Jember, Jl. Mataram No.1 Mangli Jember, Jawa Timur Indonesia \\ Email: karimaldanief@gmail.com
}

DOI: 10.35719/akselerasi.v2i1.100

\begin{abstract}
Covid-19 is a new thing that has emerged in our midst, which is a virus that is invisible but very unsettling for the community, this virus has a negative impact on everything from education, worship, to the economy. The purpose of writing this article is to determine the impact of covid and its resolution in the learning of SDNU Grenden Puger students during this pandemic, in which the learning process is carried out online at their respective homes but once a week students collect assignments to school. This research method uses descriptive qualitative approach and type of case study research. Primary data collection methods resulted from direct field work, namely the process of observation, interviews and documentation included in the discussion points. Meanwhile, the data analysis methods of Miles and Huberman's model are data reduction, data display, and conclusion or verification. While the validity of the data were: source triangulation, method triangulation and theory triangulation. The results of this research indicate that: The problems faced by students in learning during the pandemic: (1) the absence of infrastructure or facilities such as cellphones, computers, etc. (for some students). (2) Lack of understanding of technology. (3) There needs to be a new adaptation with online learning. (4) Feelings of laziness, boredom and boredom have been experienced. The obstacles faced by parents of students during online learning are: (1) They do not understand technology when their children ask questions regarding online learning applications. (2) Purchasing quotas increases than usual. (3) Difficult to get children to go to school online. Meanwhile, the obstacles faced by teachers during the Covid-19 epidemic were: (1) Not flexible in teaching, (2) inadequate learning facilities, (3) It was difficult to monitor the development of students.
\end{abstract}

Keywords: Covid-19, Online Learning, Elementary School

\footnotetext{
ABSTRAK

Covid-19 merupakan hal baru yang muncul ditengah-tengah kita, yakni sebuah virus yang tidak terlihat namun sangat meresahkan masyarakat, virus ini memberi dampak buruk dalam semua hal mulai dari pendidikan, ibadah, ekonomi. Tujuan penulisan artikel ini untuk mengetahui dampak covid dan penyelsaiannya dalam pembelajaran siswa SDNU Grenden Puger selama pandemi ini, yang mana proses pembelajaran dilakukan secara online dirumah masing-masing akan tetapi dalam seminggu sekali
} 
siswa mengumpulkan tugas ke sekolah. Metode penelitian ini menggunakan pendekatan kualitatif deskrptif dan jenis penelitian studi kasus. Metode pengumpulan data primer dihasilkan dari hasil terjun lapang langsung yakni proses observasi, wawancara dan juga dokumentasi dicantumkan pada point pembahasan. Sedangkan metode analisis data model Miles dan Huberman yaitu reduksi data, display data, dan kesimpulan atau verifikasi. Sedangkan keabsahan data yaitu: trianggulasi sumber, trianggulasi metode dan trianggulasi teori. Hasil penelitiannya ini menunjukkan bahwa: Persmaslahan yang dihadapi murid dalam pembelajaran masa pandemi: (1) tidak adanya sarana prasarana atau fasilitas seperti handphone, computer dll (bagi beberapa peserta didik). (2) Kurangnya pemahaman tentang teknologi. (3) Perlu adanya adaptasi baru dengan belajar online. (4) Rasa malas, bosan dan jenuh sudah dialami. Kendala yang dihapi orang tua murid masa pembelajaran daring yaitu: (1) Kurang paham dalam teknologi ketika anaknya bertanya terkait aplikasi belajar online. (2) Pemebelian kuota bertambah dari biasanya. (3) Sulit mengajak anak untuk sekolah online. Sednagkan kendala yang di hadpi guru pada masa Pndemi Covid-19 yaitu: (1) Tidak leluasa dalam mengajar, (2) sarana belajar yang kurang memedai, (3) Sulit nya memantau perkembangan peserta didik.

Kata Kunci: Covid-19, Pembelajaran Daring, Sekolah Dasar

\section{PENDAHULUAN}

Tahun 2020 merupakan tahun yang sangat berbeda dari tahun-tahun sebelumnya karena pada tahun ini muncul hal baru yang cukup meresahkan dunia tidak terkecuali nagara kita Indonesia. Hal baru ini adalah sebuah virus yang tentu sangat kita tidak harapkan kedatangan nya, virus ini kenal dengan nama covid 19 atau corona yang mana muncul pertama kali dari Negara China. Covid 19 ini sudah sangat merugikan masyarakat, kelompok, organisasi bahkan juga negara. Karena diketahui sangat mematikan meskipun tidak terlihat, akhirnya pemerintah mengeluarkan edaran yang mana semua kegiatan yang pada umumnya dilakukan diluar rumah (secara langsung) dalam hal ekonomi, pendidikan dll, akhirnya diganti dengan serba online (dirumah saja). Berbeda dalam hal ekonomi (pekerjaan), jika masih bisa dilakukan secara online tentu masih mending meskipun tidak maksimal, lalu bagaimana dengan orang orang yang penghasilannya tidak bisa memenuhi kebutuhan sehingga mereka harus diam di rumah mengikuti aturan pemerintah tanpa mempunyai uang untuk menafkahi keluarganya. Ada juga yang penghasilan nya tidak harian akan tetapi sama tidak ada pemasukan, seperti pegawai pabrik yang harus di PHK (pemutusan hubungan kerja) karena pabriknya tutup.

Bukan hanya dalam hal ekonomi, akan tetapi juga didalam dunia pendidikan, semua sekolah dan kampus ditutup sementara karena covid 19 ini, baik dari guru, murid, mahasiswa harus melakukan proses belajar mengajar dari rumah (online), hal ini merupakan upaya demi mencegah penularan corona. Pemerintah melakukan hal tersebut sesuai dengan solusi serta dukungan dari Organisasi Pendidikan, Keilmuan, dan Kebudayaan PBB (UNESCO) tentang pembelajaran jarak 
jauh yang inklusif ${ }^{1}$. Begitu pula dengan pemerintah kabupaten Jember yang mengeluarkan surat edaran terbaru terkait pembelajaran dari rumah (daring), dengan nomor SK 420/1402/310/2020 yang mana di perpanjang sampai 20 Juni 2020, setelah itu dilanjutkan libur semester dan tahun ajaran baru dimulai tanggal 13 Juli 2020 dengan tetap daring hingga saat ini. ${ }^{2}$

Proses pembelajaran secara langsung atau di sekolah merupakan alat kebijakan publik sebagai upaya peningkatan skill dan pengetahuan ${ }^{3}$. Selain itu, banyak juga murid yang menganggap sekolah adalah kegiatan yang menyenangkan, karena bisa berinteraksi dengan dengan nurid yang lain. Semenjak diberhentikan nya belajar di sekolah sementara, tentu banyak dampak yang akan dialami, termasuk di lembaga SDNU Grenden kecamatan Puger-jember yang mana belajar mengajar pada SDNU Grenden-Puger dilakukan sesuai anjuran pemerintah yaitu dari rumah atau online. Seperti apa dampak yang dialami siswa seperti efektivitas dalam proses belajar selama belajar online? Penulis mencoba memaparkan efektivitas pembelajaran siswa selama belajar dari rumah sekaligus dampaknya.

Tentu saja dari sebagian murid, guru, dan orang tua murid kaget tentang proses belajar mengajar yang berbeda dari sebelumnya karena mereka baru pertama kali merasakan adanya pembelajaran online yang tidak ada dipikran mereka serta tidak ingin terjadi kedatangan nya. Dalam melakukan proses belajar mengajar yang harus online, secara otomatis semua murid dan guru harus memiliki handphone dan juga memiliki kuota internet. Beragam dampak mulai dirasakan oleh guru dan murid, mulai dari sulitnya memahami pelajaran, sulitnya sinyal, sulitnya uang untuk membeli kuota internet, sulitnya dalam bermain teknologi, bahkan ada beberapa yang tidak memiliki handphone.

Pengamat pendidikan Doni Koesoema menjelaskan, setiap sekolah dan guru harus mencari solusi sekaligus cara agar proses pembelajaran berjalan efektif sesuai dengan situasi dan kondisi yang ada, artinya harus kontekstual sesuai dengan keadaan peserta didik dan wali murid, prinsipnya tidak boleh dan jangan sampai ada satu peserta didik yang dikecualikan atau terabaikan dalam proses pembelajaran saat pandemic covid ini. Setiap guru juga harus berinovasi dalam proses pemebelajaran sesuai dengan apa yang menurut murid bisa dilakukan, karena guru dan pihak sekolah lebih tau bagaimana yang terbaik untuk muridnya. ${ }^{4}$

\footnotetext{
${ }^{1}$ Agus Purwanto, Rudy Pramono, Masduki Asbari, Priyono Budi Santoso, Laksmi Mayasti Wijayanti, Choi Chi Hyun, dan Ratna Setyowati Putri, Studi Eksploratif Dampak Pandemi COVID 19 Terhadap Proses Pembelajaran Online di Sekolah Dasar, (Journal of Education, Psycology and Conseling, Vol.2 No.1 2020, Universitas Pelita Harapan Indonesia), hal.3

${ }^{2}$ SK Bupati Jember, Dr. Faida, MMR, Kebijakan Pendidikan Dalam Masa Darurat Penyebaran Covid-19, (Jember, 29 Mei 2020).

${ }^{3}$ Rizqon Halal Syah Aji,Dampak Covid 19 pada Pendidikan Indonesia: Sekolah, Keterampilan, dan Proses Pembelajara, (Jurnal Sosial\&Budaya, Vol.7 No.5 2020, Sekolah Ilmu Ekonomi Universitas Kebangsaan Malaysia), hal.396

${ }^{4}$ Dandy Bayu Bramasta, Hari Pendidikan Nasional dan Solusi Belajar di Tengah Pandemi Corona, (https://www.kompas.com/tren/read/2020/05/02/151400565/hari-pendidikan-nasional-dan-solusi-belajardi-tengah-pandemi-corona-?page=all ).
} 
Menurut Isman pembelajaran secara daring atau online merupakan pemanfaatan jaringan internet dalam proses pembelajaran, dengan pembelajaran daring siswa memiliki keleluasaan baik dalam hal waktu dan tempat. Para murid dapat berinteraksi dengan guru melalui beberapa aplikasi seperti zoom, meet, google classroom, dan bisa whatsapp group 5 . Akan tetapi tidak semua bisa memahami apa yang dijelaskan guru, karena yang secara langsung saja belum tentu paham apalagi yang jarak jauh atau via aplikasi, semua itu tergantung karakteristik dan kesungguhan murid. Nakayama mengungkapkan bahwa dari semua literatur e-learning mengindikasikan bahwa tidak semua peserta didik akan berhasil atau sukses dalam pembelajaran online, dikarenakan faktor lingkungan belajar dan karakteristik peserta didik ${ }^{6}$.

Dalam hal pembelajaran daring guru dan pihak sekolah SDNU Grenden-Puger sudah bekerja secara maksimal untuk tetap melaksanakan pemebelajaran daring sesuai dengan peraturan dari pemerintah, dan bagi murid yang tidak memiliki handphone bisa numpang keteman nya yang memiliki handphone yang rumahnya paling dekat untuk dijangkau, nantinya saat seminggu sekali ada pengumpulan tugas bagi semua murid ke sekolah, sembari mengumpulkan tugas guru juga menjelaskan dan mengulang kembali secara singkat pelajaran yang sudah diterima oleh murid secara online dalam minggu sebelumnya.

\section{METODE}

Adapun metode penelitian menggunakan pendekatan kualitatif deskrptif dan jenis penelitian studi kasus. Dalam suatu penelitian yang menggunakan metode kualitatif harus dimulai dengan ide yang dinyatakan dengan pertanyaan (research questions), yang mana dari pertanyaan tersebut akan menentukan dalam hal pengumpulan data dan bagaimana cara menganalisis nya. Metode kualitatif bersifat dinamis, yakni selalu terbuka akan adaya perubahan, penambahan dan penggantian selama proses analisa ${ }^{7}$. Penulis juga menggunakan studi kasus yang mana secara khusus untuk menjelaskan apa dan bagaimana model pembelajaran daring di SDNU Grenden Puger dan juga apa saja kendala yang dialami. Seperti yang kita ketahui bahwa studi kasus bertujuan khusus untuk menjelaskan dan memahami objek yang diteliti, baik dari kasus individu, peristiwa dan kelompok. Metode pengumpulan data primer dihasilkan dari hasil terjun lapang langsung yakni proses observasi, wawancara dan juga dokumentasi dicantumkan pada point pembahasan. Sedangkan metode analisis data model Miles dan Huberman ${ }^{8}$ yaitu reduksi data, display data, dan kesimpulan atau verifikasi tentang model pelaksanaan pembelajaran open and distance larning. Sedangkan keabsahan data yaitu: trianggulasi sumber, trianggulasi metode dan trianggulasi teori.

\footnotetext{
${ }^{5}$ Wahyu Aji Fatma Dewi, Dampak Covid 19 Terhadap Implementasi Pembelajaran Daring di Sekolah Dasar, (Jurnal Ilmu Pendidikan, Vol. 2 No. 1, Universitas Kristen Satya Wacana), hal. 56

${ }^{6}$ Ibid.

${ }^{7}$ Yoni Ardianto, Memahami Metode Penelitian Kualitatif, (https://www.djkn.kemenkeu.go.id/artikel/baca/12773/Memahami-Metode-Penelitian-Kualitatif.html ) ${ }^{88}$ Milles dan Huberman, Analisis Data Kualitatif, (Jakarta: Universitas Indonesia Press, 1992), hal. 16.
} 


\section{HASIL DAN PEMBAHASAN}

Menteri Pendidikan Nadiem Anwar Makarim telah mengeluarkan surat edaran nomor 3 tahun 2020, dengan nomor SK 36962/MPK.A/HK/2020 tentang pelaksanaan Pendidikan dalam masa Darurat Corona Virus Disease (COVID 19) maka kegiatan belajar dilakukan secara daring atau online dalam rangka pencegahan penyebaran Covid $19^{9}$. Artinya semua kegiatan yang melibatkan kumpulnya banyak orang ditiadakan, seperti belajar, bekerja dan beribadah harus dari rumah saja.

Temuan dalam penelitian di SDNU Grenden Puger ialah tentang dampak/akibat dari pandemi covid 19 terhadap pembelajaran di SDNU Grenden Puger. Semenjak adanya perintah untuk meliburkan kegiatan belajar mengajar di sekolah, artinya harus melakukan belajar mengajar dari jarak jauh atau dari rumah, banyak hal yang tidak enak dirasakan oleh para siswa, orang tua siswa dan juga guru. Karena biasanya para siswa belajar secara langsung tatap muka di dalam kelas dengan guru, sekarang hanya terbatas lewat handphone, yang manaaplikasi yang digunakan ialah WhatsApp grup dan google classroom. Beberapa hal mulai dirasakan oleh murid, orang tua murid dan juga guru. Mulai dari ketidaknyamanan, kefektifan, bosan, intinya tidak maksimal. Para peserta didik yang biasanya senang jika masuk sekolah karena bisa berinteraksi langsung dengan temantemannya, kini sudah harus diam dirumah masing-masing karena imbas dari covid 19. Banyak orang tua peserta didik di SDNU Grenden Puger yang mengeluh akan keadaan yang menimpa putra-putri mereka, disisi lain mereka juga sadar bahwa ini perintah dari pemerintah, artinya pihak sekolah juga harus menuruti perintah dari atasan (Kementrian Pendidikan). Akhirnya pihak sekolah membuat keputusan agar para siswa dapat datang ke sekolah dalam seminggu sekali untuk mengumpulkan tugas sekaligus diberi penjelasan oleh guru atas pelajaran yang sudah diterima selama seminggu sebelumnya dari rumah. Kebijakan pihak sekolah ini ialah hasil rapat para pihak sekolah setelah menuai banyak kritik dan keluhan yang tidak enak dari orang tua siswa, dan sekaligus yang dirasakan para guru juga tidak enak jika belajar lewat handphone. Berikut adalah keluhan sekaligus kendala selama pembelajaran dari rumah:

\section{Dampak Covid-19 Terhadap Cara Belajar Peserta Didik}

Beberapa dampak yang dirasakan oleh murid SDNU Grenden Puger, khususnya kelas $3 \& 4$ (sebagai responden dalam penelitian ini) selama proses belajar mengajar dari rumah adalah: Pertama, sarana dan prasarana yang kurang memadai yang ada dirumah, karena fasilitas dalam pembelajaran itu sangat peting dan disini masih ada beberapa siswa yang masih tidak mempunyai handphone. Sedangkan dari pihak sekolah atau Pendidikan tidak mungkin memberi fasilitas satupersatu setiap murid. Hal ini tentu sangat dikeluhkan oleh para murid karena mereka tidak maksimal/efektif dalam belajar. Fasilitas yang dibutuhkan bisa seperti handphone, laptop dan

\footnotetext{
${ }^{9}$ Wahyu Aji Fatma Dewi, Dampak Covid 19 Terhadap Implementasi Pembelajaran Daring di Sekolah Dasar, (Jurnal Ilmu Pendidikan, Vol. 2 No. 1, Universitas Kristen Satya Wacana), hal. 57-58
} 
computer. Akhirnya pihak sekolah memutuskan bagi murid yang tidak memiliki handphone bisa numpang ke temennya yang punya handphone, akan tetapi ini bukan paksaan. Tujuannya agar murid tersebut tidak ketinggalan jauh pelajaran.

Kedua, bagi murid yang sudah ada fasilitas handphone kendala nya adalah kurang nya pemahaman dalam hal teknologi, mereka belum mengenal dunia teknologi/aplikasi yang digunakan dalam belajar online, untuk anak se-usia kelas $3 \& 4$ yang mereka tau dari handphone hanya game. Aplikasi yang mereka pahami dalam belajar online cuma aplikasi whatsapp, akan tetapi tidak maksimal karena anak-anak banyak tidak menyimak. Ketiga, kendala nya adalah terkait adaptasi mereka dengan keadaan sekarang yakni belajar online yang mana tidak seperti biasanya mereka bisa berinteraksi dengan guru dan teman nya, sekarang hanya terbatas dari handphone saja. Dengan adanya hal ini secara otomatis para murid harus menyesuaikan diri dengan belajar yang mana dampaknya mengganggu daya paham mereka terhadap suatu pelajaran.

Keempat, suatu hal yang tidak seperti biasanya tentu akan menghasilkan hasil yang tidak biasa juga (berbeda). Kendala selanjutnya ialah para murid/siswa sudah merasa bosan dan jenuh jika hanya belajar dari rumah, karena mereka tidak bisa berinteraksi sekaligus bermain dengan teman-teman nya yang biasa mereka temui di sekolah. Butler menyatakan, kebutuhan yang dibutuhkan siswa dalam belajar dan lingkungan belajar adalah searah atau sebangun. Jika penawaran kursus di sekolah menengah setempat terbatas, maka akan menghasilkan kurangnya tantangan dan kebosanan ${ }^{10}$. Dari keempat kendala yang telah dialami para murid atau siswa bisa kita ketahui tentu kurang maksimal dan kurang efektif dalam proses belajar mengajar jarak jauh (online).

\section{Kendala Orang Tua Terhadap Belajar Anak Selama Pandemi Covid-19}

Bukan hanya peserta didik yang mendapat kendala akibat dampak Covid 19 ini, akan tetapi orang tua murid atau siswa juga mendapat kendala. Pasalnya karena mereka yang membiayai/menfasilitasi putra-putrinya agar bisa sekolah. Ada beberapa kendala yang dialami oleh beberapa wali murid akibat dari covid-19 terhadap dunia Pendidikan, diantaranya: Pertama, dalam hal teknologi. Beberapa dari wali murid tidak begitu paham betul dalam hal teknologi/aplikasi yang dipakai dalam pemebelajaran online, mereka mengeluhkan dan juga bingung ketika putra putrinya menanyakan terkait aplikasi yang dipakai saat belajar online, yang kebanyakan wali murid pahami terkait aplikasi hanyalah whatsapp. Dan karena posisi belajarnya dirumah otomatis tempat pertanyaan siswa pada orang tuanya. Yang mana akibat dari ketidaktahuan terhadap teknologi ini mengganggu maksimalnya suatu pembelajaran.

\footnotetext{
${ }^{10}$ Agus Purwanto, Rudy Pramono, Masduki Asbari, Priyono Budi Santoso, Laksmi Mayasti Wijayanti, Choi Chi Hyun, dan Ratna Setyowati Putri, Studi Eksploratif Dampak Pandemi COVID 19 Terhadap Proses Pembelajaran Online di Sekolah Dasar, (Journal of Education, Psycology and Conseling, Vol.2 No.1 2020, Universitas Pelita Harapan Indonesia), hal.6
} 
Kedua, kendala selanjutnya yang dirasakan oleh wali murid/siswa ialah tentang biaya dalam membeli kuota. Seperti yang kita ketahui Bersama, bahwa covid 19 ini bukan hanya berdampak terhadap kesehatan dan pedidikan saja, melainkan berdampak terhadap perekonomian juga. Mungkin bagi orang-orang yang ekonominya menengah keatas bisa tetap santai, akan tetapi kebanyakan wali murid disini ternyata ekonomi nya ada yang menengah kebawah. Untuk pembelajaran online selama beberapa bulan ini tentunya memerlukan membeli kuota internet yang lebih banyak dari biasanya dan otomatis menambah pengeluaran uang. Ketiga, kendala selanjutnya ialah sulitnya mengajak anak dalam belajar online. Seperti yang telah disebutkan diatas pada dampak terhadap murid, yaitu murid sudah bosan belajar dari rumah karena mereka sudah tidak tahan ingin segera berinteraksi dengan teman-teman nya di sekolah, mereka ingin seperti biasanya yaitu dapat bermain dengan teman sekolah nya. Dari kebosanan itulah wali murid merasa sulit jika mengajak anaknya untuk belajar online. Tentu saja dari kendala tersebut mengganggu keefektifan dalam pembelajaran online.

Selama belajar online berlangsung, seorang orangtua harus meluangkan waktu lebih untuk anaknya, karena saat proses belajar mengajar wali murid harus berada disisi putra-putrinya dan medampingi sampai pembelajaran online selesai. Hikmah yang bisa diambil ialah para wali murid bisa lebih perhatian serta mengawasi putra putrinya dan juga wali murid bisa tahu rasanya mendidik anak seperti yang dirasakan oleh para guru di sekolah.

\section{Kendala yang dialami Guru Saat Mengajar Pada Masa Pandemi Covid-19}

Selain murid dan wali murid yang mempunyai kendala terkait belajar online akibat dari covid 19, posisi guru juga mendapatkan kendala dalam proses pembelajaran online. Yang mana imbas dari kendala tersebut tentu menyangkut efektivitas dalam suatu pembelajaran online. Jika menyangkut dalam hal keefektifan belajar, guru merupakan orang yang mempunyai peran penting, karena tugasnya yang harus memberi pemahaman terhadap murid dan juga mendidik. Dalam dunia Pendidikan, guru adalah sebagai pemimpin yang memberikan materi dan sebagai pendidik agar anak pintar serta ber akhlak terpuji. ${ }^{11}$ Menurut M.A Ametambun dan Djamarah, guru ialah orang yang bertanggung jawab terhadap Pendidikan murid-murid, baik secara individual atau klasikal, baik disekolah maupun diluar sekolah. Oleh karena itu seorang guru harus menguasai berbagai kompetensi dari pedagogis, kepribadian, social masyarakat, dan juga professional. ${ }^{12}$

Dalam proses pembelajaran online para guru SDNU Grenden Puger menggunakan aplikasi whatsapp group, terkadang memakai google classroom. Dalam hal ini beberapa guru juga memiliki kendala yaitu kurang maksimalnya dalam mengajar/menyampaikan suatu pelajaran. Hal itu disebabkan karena beberapa guru belum beradaptasi dengan keadaan belajar online, yang mana

\footnotetext{
${ }^{11}$ Heriyansyah, Guru Adalah Manajer Sesungguhnya Di Sekolah, (Jurnal Manajemen Pendidikan Islam, Vol.1 No.1, Januari 2018), hal.119

${ }^{12}$ Ibid, hal.120
} 
sebelumnya tidak pernah melakukan hal demikian (belajar online). Akan tetapi namanya seorang harus bisa melewati semua itu, karena guru dituntut serba bisa atau professional agar dapat memberi pemahaman yang terbaik kepada para murid-muridnya.

Dari semua kendala yang telah disebutkan diatas, mulai dari kendala yang dialami murid, wali murid dan juga guru akibat dari covid 19 yang mengharuskan melakukan pembelajaran secara online, tentu bisa kita ketahui dalam hal efektivitas, sangat tidak efektif atau tidak maksimal. Setelah dampak-dampak tersebut dirasakan, para wali murid mengeluh akan keadaan ini dan meminta putra-putrinya bisa sekolah seperti biasanya, akhirya pihak sekolah merapatkan terkait hal tersebut utuk mencari jalan keluar atau titik temu. Setelah melakukan rapat dengan mempertimbangkan beberapa pertimbangan terkait kepentingan bersama, akhirnya pihak sekolah membuat kebijakan sebagai berikut: (1) Para murid/siswa setiap minggu datang ke sekolah untuk megumpulkan tugas yang sudah diberikan saat pembelajaran online. (2) Sembari mengumpulkan tugas, para murid juga diberikan penjelasan singkat oleh guru terkait di dalam kelas sekitar satu jam, atas pelajaran yang sudah diterimanya seminggu sebelumnya saat pembelajaran online. (3) Dalam satu hari hanya boleh satu kelas yang datang ke sekolah. Contoh: hari senin kelas 1 , hari selasa kelas 2 dan seterusnya. (4) Dengan syarat harus tetap mematuhi protokol kesehatan, seperti cuci tangan terlebih dahulu, memakai masker, dan jaga jarak.

Akhirnya kami menemukan inovasi baru agar mereka tetap semangat belajar dari rumah dan juga tidak monoton di dalam kelas, yaitu: (1) Memberikan hadiah bagi yang bisa menjawab pertanyaan. Dengan adanya hal tersebut para murid dirumahnya pasti belajar meskipun sebentar karena ingin dapat hadiah saat mengumpulkan tugas ke sekolah. (2) Menyelingi nyanyian saat pelajaran dikelas untuk kelas 4 kebawah, akan tetapi nyanyian tersebut yang mengandung unsur Pendidikan/pelajaran, bukan asal asalan. (3) Untuk kelas 4 keatas kami selingi dengan nonton film/video yang berkaitan dengan mata pelajaran, terkadang juga film yang menginspirasi. (4) Kami juga sempat membagikan susu bagi murid kelas 5, agar mereka senang, semangat dan juga sehat.

Proses Pembelajaran pada masa pandemi Covid-19 Pihak sekolah meliburkan sekolah tatap muka dengan alasan karena perintah dari kementerian pendidikan, selain itu juga karena khawatir para murid/siswanya bisa tertular, karena gejala atau tanda-tanda tadi virus ini sangat sepele dan sudah sering kita tahu dari dulu. Gejala umum dari virus ini beragam, yang mana pihak Pusat Pengendalian dan Pencegahan Penyakit atau the Centers For Disease Control and Prevention $(C D C)$ baru-baru ini menambahkan 3 gejala baru dari covid 19. Total gejala umum sekarang 
menjadi Sebelas (11) gejala, antara lain seperti batuk, demam, sesak napas, kelelahan, tubuh terasa sakit, sakit kepala, kehilangan rasa atau bau, sakit tenggorokan, pilek, mual dan diare. ${ }^{13}$

Dengan adanya pembelajaran online para siswa akhirnya terkendala dalam banyak hal, terutama dalam pemahaman teknologi (aplikasi), seperti google classroom, zoom dll. Dan mereka tidak bisa berinteraksi secara langsung dengan teman-temann dan gurunya. Isman menyebutkan bahwa pembelajaran online merupakan pemanfaatan jaringan internet dengan berbagai aplikasi, dengan ini para siswa dan guru dapat berinteraksi dengan leluasa tanpa dibatasi waktu dan tempat ${ }^{14}$. Akan tetapi pendapat tersebut tidak sesuai dengan keadaan para murid SDNU Grenden Puger yang mana ada beberapa yang tidak memiliki fasilitas handphone dan juga banyak yang tidak memahami teknologi (aplikasi).

Tentu saja dengan berbeda nya cara belajar saat ini membuat para murid bosan, jenuh. Karena sama halnya dengan berpindah lingkungan mereka perlu adaptasi, yang mana efek dari model pembelajaran online ini membuat murid sulit paham. Nakayama menyatakan dari pembelajaran tidak semua peserta didik bisa paham, semua itu karena faktor lingkungan dan karakteristik peserta didik ${ }^{15}$. Butler juga menyebutkan, kebutuhan dalam belajar dan lingkungan belajar harus searah, jika hanya terbatas maka akan timbul kurangnya tantangan serta muncul kebosanan ${ }^{16}$.

Selain para murid yang bosan karena perlu adaptasi, para orangtua murid juga kesal dengan pembelajaran online, karena sejatinya proses pembelajaran secara langsung atau disekolah merupakan alat kebijakan publik sebagai upaya peningkatan skill dan pengentahuan ${ }^{17}$. Akhirnya beberapa dari orang tua murid mengeluh ke pihak sekolah dengan keadaan yang terjadi saat ini, mereka ingin putra putrinya bisa masuk sekolah seperti biasanya. Pihak sekolah menanggapi dengan baik akan tetapi tidak bisa masuk begitu saja, perlu dirapatkan terlebih dahulu agar mendapatkan hasil yang baik bagi para muridnya akan tetapi tidak sekiranya tidak mengindikasikan tertularnya covid 19. Seperti yang disebutkan Doni Koesoema sang pengamat pendidikan, para guru harus mencari solusi agar pembelajaran tetap efektif sesuai dengan kondisi yang ada dan juga

\footnotetext{
${ }^{13}$ Ahmad Naufal Dzulfaroh, Bertambah 3 Gejala Baru, Ini Daftar 11 Gejala Covid-19 Dari CDC, Kompas.com 26 Juni 2020. (https://www.kompas.com/tren/read/2020/06/26/122424165/bertambah-3gejala-baru-ini-daftar-11-gejala-covid-19-dari-cdc?page=all )

${ }^{14}$ Wahyu Aji Fatma Dewi, Dampak Covid 19 Terhadap Implementasi Pembelajaran Daring di Sekolah Dasar, (Jurnal Ilmu Pendidikan, Vol. 2 No. 1, Universitas Kristen Satya Wacana), hal. 56

${ }^{15}$ Ibid.

${ }^{16}$ Agus Purwanto, Rudy Pramono, Masduki Asbari, Priyono Budi Santoso, Laksmi Mayasti Wijayanti, Choi Chi Hyun, dan Ratna Setyowati Putri, Studi Eksploratif Dampak Pandemi COVID 19 Terhadap Proses Pembelajaran Online di Sekolah Dasar, (Journal of Education, Psycology and Conseling, Vol.2 No.1 2020, Universitas Pelita Harapan Indonesia), hal.6

${ }^{17}$ Rizqon Halal Syah Aji,Dampak Covid 19 pada Pendidikan Indonesia: Sekolah, Keterampilan, dan Proses Pembelajaran, (Jurnal Sosial\&Budaya, Vol.7 No.5 2020, Sekolah Ilmu Ekonomi Universitas Kebangsaan Malaysia), hal.396
} 
harus berinovasi, karena para guru/pihak sekolah lebih paham terkait kondisi para anak didiknya dan lebih tau bagaimana yang terbaik untuk mereka ${ }^{18}$.

Setelah pihak sekolah melakukan rapat akhirnya menemukan titik temu yang diambil yakni siswa dapat datang ke sekolah seminggu sekali. Dengan syarat perhari nya hanya satu kelas yang datang, tetap mematuhi protokol kesehatan. Para murid datang ke sekolah guna mengumpulkan tugas yang sudah dipelajari selama pelajaran online dari seminggu sebelumnya. Disamping mengumpulkan tugas, para murid juga diberi penjelasan singkat oleh guru di kelas atas pelajaran yang sudah diterimanya. Pihak sekolah sengaja cuma memberikan waktu singkat kepada guru untuk menjelaskan karena biar tidak terlalu lama berkerumun, oleh karena itu para guru harus betul-betul menguasai pelajaran, pedagogis, kepribadian, sosial masyarakat, dan juga harus profesional $^{19}$.

\section{KESIMPULAN DAN SARAN}

Proses pembelajaran di SDNU Grenden Puger ialah dilakukan secara daring (online), dengan menggunakan aplikasi WhatsApp grub dan google classroom. Akan tetapi semua ini berjalan tidak maksimal yang mana menuai banyak kritik dan kendala bagi murid, wali murid, dan guru. Bagi pesserat didik kendalanya: (1) tidak adanya sarana prasarana atau fasilitas seperti handphone, computer dll (bagi beberapa murid/siswa). (2) Kurangnya pemahaman tentang teknologi. (3) Perlu adanya adaptasi baru dengan belajar online. (4) Rasa malas, bosan dan jenuh sudah dialami. Bagi orang tua peserat didik: (1) Kurang paham dalam teknologi ketika anaknya bertanya terkait aplikasi belajar online. (2) Pemebelian kuota bertambah dari biasanya. (3) Sulit mengajak anak untuk sekolah online. Bagi Guru ialah: (1) Tidak leluasa dalam mengajar, (2) sarana belajar yang kurang memedai, (3) Sulit nya memantau perkembangan peserta didik.

Penyelesaian sekolah dan yang di alami orang tua peserta didik di SDNU Grenden dilakukan pencegarhan (1) Para murid/siswa setiap minggu datang ke sekolah untuk megumpulkan tugas yang sudah diberikan saat pembelajaran online. (2) Sembari mengumpulkan tugas, para murid juga diberikan penjelasan singkat oleh guru terkait di dalam kelas sekitar satu jam, atas pelajaran yang sudah diterimanya seminggu sebelumnya saat pembelajaran online. (3) Dalam satu hari hanya boleh satu kelas yang datang ke sekolah. (4) Dengan syarat harus tetap mematuhi protokol kesehatan, seperti cuci tangan terlebih dahulu, memakai masker, dan jaga jarak. Tujuannya demi kebaikan dan kenyamanan bersama.

\footnotetext{
${ }^{18}$ Dandy Bayu Bramasta, Hari Pendidikan Nasional dan Solusi Belajar di Tengah Pandemi Corona, (https://www.kompas.com/tren/read/2020/05/02/151400565/hari-pendidikan-nasional-dan-solusi-belajardi-tengah-pandemi-corona-?page=all).

${ }^{19}$ Heriyansyah, Guru Adalah Manajer Sesungguhnya Di Sekolah, (Jurnal Manajemen Pendidikan Islam, Vol.1 No.1, Januari 2018), hal.119
} 


\section{DAFTAR PUSTAKA}

Agus Purwanto, Rudy Pramono, Masduki Asbari, Priyono Budi Santoso, Laksmi Mayasti Wijayanti, Choi Chi Hyun, dan Ratna Setyowati Putri. (2020). Studi Eksploratif Dampak Pandemi COVID 19 Terhadap Proses Pembelajaran Online di Sekolah Dasar, (Journal of Education, Psycology and Conseling, Vol.2 No.1 2020, Universitas Pelita Harapan Indonesia.

Aji, Rizqon Halal Syah. (2020). Dampak Covid 19 pada Pendidikan Indonesia: Sekolah, Keterampilan, dan Proses Pembelajara, (Jurnal Sosial\&Budaya, Vol.7 No.5, Sekolah Ilmu Ekonomi Universitas Kebangsaan Malaysia).

Ardianto, Yoni. (2019). Memahami Metode Penelitian Kualitatif, (https://www.djkn.kemenkeu.go.id/artikel/baca/12773/Memahami-Metode-PenelitianKualitatif.html )

Bramasta, Dandy Bayu. (2020). Hari Pendidikan Nasional dan Solusi Belajar di Tengah Pandemi Corona, (https://www.kompas.com/tren/read/2020/05/02/151400565/hari-pendidikannasional-dan-solusi-belajar-di-tengah-pandemi-corona-?page=all ).

Dewi, Wahyu Aji Fatma, Dampak Covid 19 Terhadap Implementasi Pembelajaran Daring di Sekolah Dasar, (Jurnal Ilmu Pendidikan, Vol. 2 No. 1, Universitas Kristen Satya Wacana), hal. 56

Dzulfaroh, Ahmad Naufal. (2020). Bertambah 3 Gejala Baru, Ini Daftar 11 Gejala Covid-19 Dari CDC, Kompas.com $26 \quad$ Juni. (https://www.kompas.com/tren/read/2020/06/26/122424165/bertambah-3-gejala-baru-inidaftar-11-gejala-covid-19-dari-cdc?page=all )

Hariyanti, Mey. (2018). Analisis Data Kualitatif Miles Dan Huberman, Psikologi UIN Maliki Malang, 28 Mei. (https://www.kompasiana.com/meykurniawan/analisis-data-kualitatif-milesdan-hubermen_556c450057937332048b456c )

Heriyansyah. (2018). Guru Adalah Manajer Sesungguhnya Di Sekolah, (Jurnal Manajemen Pendidikan Islam, Vol.1 No.1, Januari.

Milles dan Huberman. (1992). Analisis Data Kualitatif, Jakarta: Universitas Indonesia Press.

SK Bupati Jember, Dr. Faida, MMR, Kebijakan Pendidikan Dalam Masa Darurat Penyebaran Covid-19, (Jember, 29 Mei 2020). 